\title{
Prevalence, Risk Factors and Impacts of Schistosomal and Intestinal Parasitic Infections Among Rural School Children in Sohag Governorate
}

\author{
H. M. El-Masry; Y. A. Ahmed; A. A. Hassan; S. Zaky*; E. S. Abd-Allah**; \\ E. A. El-Moselhy***; Y. A. Baraka*** And M. A. Abdel-Rahem $* * * *$ \\ Departments of Pediatrics; Tropical Medicine*; Community Health Nursing**; Community \\ Medicine*** and Parasitology**** \\ Faculty of Medicine and Nursing, Al-Azhar and Zagazig University
}

\begin{abstract}
Parasitic diseases represent a major cause of morbidity and mortality in childhood in most parts of the world. Hygiene and play habits make children especially vulnerable to schistosomal and parasitic infections. The aim of this study is to define the prevalence of different types of parasitic infections, to define their risk factors and to determine their impacts on health and scholastic absenteeism and achievement of rural school students in Sohag Governorate, Egypt. A cross-section, analytical study design was chosen to perform this research on 960 rural school students. All the students were interviewed and examined clinically and laboratory. The study showed that $38.5 \%$ of the students were infected by parasites. Entaemoeba histolytica, Enterobius vermicularis and Giardia lamblia had the highest percentages, 20.4\%, $16.6 \%$ and $15.2 \%$, respectively. Male sex, last birth order, poor personal hygiene, low socioeconomic level, $\geq 3$ infected siblings, previous parasitic infections and no early consultation for therapy were important risk factors $(\mathrm{ORs}=1.41,2.32,2.63,2.86,4.17,9.80$ and 10.83, respectively). Also, $29.2 \%$ and $31.6 \%$ of infected students were below the $5^{\text {th }}$ percentiles as regard weight-for-age and height-for-age, respectively. Anemia was present among $52.4 \%$ of infected students. Further, $3.2 \%$ of them had hepatomegaly. Also, $37.8 \%$ and $41.1 \%$ of infected students had $0-3$ and 4-6 days/month absent, respectively, while, $34.3 \%$ of infected students had a scholastic achievement $<50.0 \%$. Improving personal and environmental hygiene and regular screening, treatment and health education for students as regard parasitic infections in Egypt is recommended.
\end{abstract}

\section{Introduction}

Although all infectious agents in humans are parasites, by convention, parasitic diseases are defined as those caused by protozoa or helminthes (ChaconCruz and Mitchell, 2007). The burden of disease caused by infection with schistosomiasis and soil-transmitted helminthes (STH) remains enormous. About 2 billion people are affected worldwide, of whom 300 million suffer associated severe morbidity. These infections represented more than $40.0 \%$ of the disease burden caused by all tropical diseases, excluding malaria (WHO/WER, 2006). Hygiene and play habits make children especially vulnerable to schistosomal and STH infections. There are about 400 million school-age children infected. They are often physically and intellectually compromised by anemia, leading to attention deficits, learning disabilities, school absenteeism and higher dropout rates (WHO, 2001). The failure to treat school-age children therefore hampers child development, yields a generation of adults disadvantaged by the irreversible sequelae of infection, and compromises the economic development of communities and nations (WHO/WER, 2006). So, parasitic diseases represent a major cause of morbidity and mortality in childhood in most parts of the world, as parasites are endemic in many parts of the world with no specific area is spared. Although, infections due to protozoa and helminthes have received relatively little attention (Mahmoud, 1983). So, unfinished agenda for the fight against infectious parasitic 
diseases might never come to an end (Remme, 2007).

School children are considered one of the most important sectors of population due to their continuous growth and development at all levels. They are a vulnerable group and great attention should be paid for them (Abdel-Wahab and Mahmoud, 1987). Also, parasitic infection is a major public health problem in children worldwide, especially in developing societies. It produces nutritional deficiencies, especially among chronically infected children (Khalil, 1982 and El-Shobaki et al., 1990).

Un-hygienic living conditions give rise to increased prevalence of parasitic infections. Intestinal parasites are transmitted either directly or indirectly (Mahmoud, 1983 and Gamboa et al., 1998). Moreover, the prevalence of parasitic infection differ in different communities according to many factors, which include social and environmental characters of the community, health habits of the community personnel and technical methods used in diagnosis of parasites (El-Gammal et al., 1995).

It is estimated that the prevalence of parasitic infections allover the world from 1975 to 1995 were the following: $20.0 \%$ (1.3 billion) of the world population infected with ascariasis, $20.0 \%$ (1.3 billion) infected with hookworms, 3.3\% (200 million) infected with giardiasis, $2.5 \%$ (150 million) infected with schistosomiasis, $1.08 \%$ (65 million) infected with cestodes, $1.0 \%$ (60 million) infected with amebiasis and $0.6 \%$ (35 million) infected with stronglyoidsias (Michael, 1997).

In Egypt, $56.0 \%$ and $47.0 \%$ of children are worryingly suffering from intestinal parasites and anemia, respectively (UNICEF, 2000). In further details; 40.4\%, $22.4 \%, 8.9 \%, 8.7 \%, 6.3 \%, 5.4 \%$ and $1.9 \%$ of the Egyptian school children were suffering from Enterobius vermicularis, Schistosoma (S.) haematobium, Giardia lamblia, S. mansoni, Ascaris lumbricoides, Entamoeba (E.) histolytica and Ancylostoma duodenale, respectively (El-Gammal et al., 1995).

Growth in childhood is determined by environmental factors such as nutrition (which is influenced by infection) and illness (Heald and Gong, 1999). Nutritional anthropometric measures remain the most practical and useful mean for the assessment of the nutritional status of the population particularly children. It is the single universally applicable, inexpensive and non-invasive method and reflects both health and nutrition and predicts performance (DeOnis and Habicht, 1996). The height and weight retardation could be used as a useful indicator to identify high-risk children with poor health, under nutrition and low socioeconomic status (Habicht et al., 1974; Delgado et al., 1991 and Kafafi \& Abdel-Mottaleb, 1992).

\section{Study Objectives}

\section{A- Ultimate objective:}

Improving quality of health of the school children in Egypt.

\section{B- Immediate objectives:}

1- To determine the prevalence of parasitic infection among rural school children in Sohag Governorate, Egypt.

2- To determine the sociodemographic and environmental risk factors for parasitic infection among rural school children in Sohag Governorate, Egypt.

3- To determine the impact of parasitic infection on the health and scholastic achievement of rural school children in Sohag Governorate, Egypt.

\section{Subjects And Methods}

\section{A- Technical Design}

I- Study Setting: This study was conducted in El-Huridyh village, a randomly selected village in Tahta District, Sohag Governorate.

II- Study Sample: One primary and one preparatory school in the village were included in the present study. In each school all of the students were included. The total number of students was 960 . The students aged from 6 to 16 years. For each positive case a control case was chosen from the students' class list, the name after the positive case. Siblings of positive cases and controls were also examined to define percent of the positives among them.

III- Study Design: A cross-section, analytical study design was chosen to investigate the current research problem. 


\section{H. M. El-Masry et al}

\section{IV- Study Tools and Methods:}

1- Interview questionnaire: It was used to collect data relevant to topic of the study. Student's parents, also, were submitted to an interview. Scholastic achievement was determined according to results of the first term exam; excellent $\quad(\geq 85.0 \%)$, very good $(\geq 75.0 \%), \quad$ good $(\geq 65.0 \%)$, passed $(\geq 50.0 \%)$ and failed $(<50.0 \%)$. Sanitary measures were assessed by observation and asking about presence of pure water supply, private latrines and sewage carriage system inside houses of the examined students and classified accordingly to bad (only one of them was present), fair (2 of them were present) and good ( all of them were present).

2- Diagnosis of childhood parasitic infections: All students included in the study had undergone full laboratory examinations for stool and urine. Fresh stool samples were taken from all students in morning and examined carefully by microscope. The following methods were used: a) Direct smears to detect any type of parasitic infection (Garcia and Bruckner, 1997). This test includes a wet preparation with/ without iodine (must be performed within 30 minutes of collection) to identify motile trophozoites and a formalin-ethyl acetate concentration step to identify amebic cysts and trophozoites. E. histolytica is indisting-uishable from the noninvasive and more prevalent $E$. dispar, with the exception that $E$. histolytica trophozoites may contain ingested red blood cells (RBCs) (Nesbitt et al., 2004 and Chacon-Cruz \& Mitchell, 2007). b) Modified Kato thick smear technique (Peters et al., 1980). c) Examination of Enterobius vermicularis was done by scotch tape method. While, urine samples were examined for $S$. haematobium.

3- Clinical examinations: Physical examinations; both general and local were done; pelvi-abdominal ultra sonography was done for cases with hepatosplenomegaly and/or schistosomiasis. Anthropometric measurements (height and weight to define height-for-age and weight-for-age) and hemoglobin level were done. Weight $(\mathrm{kg})$ was measured by using a portable balance, with a child wear light outer garment and without shoes. Height (cm) was measured in standing position by using a measuring stick, which was fixed to a vertical wall. Values of weight and height were applied to the percentiles, where normal values were considered $5^{\text {th }}-95^{\text {th }}$ percentiles (Vaughan III, 2004). The calculation of percentiles was based on normalized curves. Percentiles from the reference population have a uniform distribution and are useful since they are easy to interpret (Van Den et al., 1996). Weight-for-age reflects body mass relative to chronological age. It is the most widely used indicator, because the simplicity of collecting only one measurement (Gorstein, 1989). Height-for-age reflects achieved linear growth and its deficits indicate long-term cumulative inadeq-uacies of health or nutrition (WHO, 1995). Grams of hemoglobin per liter of blood are an index of blood oxygen-carrying capacity. Measurement of hemoglobin in whole blood is the most widely used screening test for anemia. Hemoglobin concentration (gram/ deciliter, g/dl) was estimated by using Drabkin's photometric method (Boehringer kit) to determine the anemic students. Anemia is considered corresponding to a level of hemoglobin concentration of $<11 \mathrm{~g} / \mathrm{dl}$ (EI-Zanaty et al., 2000).

\section{B- Operational Design}

\section{I- Preparatory Phase:}

1- Administrative phase: Permission to implement the study was obtained from Health Insurance Affairs.

2- Pilot study: Before starting the practical phase a pilot study was done on 50 students and siblings of the positive cases to test the questionnaire. The questionnaire was accordingly modified. The pilot study was guided by the following tasks:

i. Testing the form design, content and language at the study sites.

ii. Measuring the time and resources needed for the fieldwork. 
II- Practical Phase: This phase took about 3 months. The data were collected through field visits. Every positive case and his/her controls were visited in their homes to observe the domestic sanitary conditions and to examine their sibling(s).

III- Analysis and Reporting Phase: Odds ratio (OR) with 95\% confidence interval (CI) and Yates corrected chisquare $\left(\chi^{2}\right)$ were used as tests of significance. The significance level for $\chi^{2}$ was accepted if the P-value $\leq 0.05$.

\section{Results}

The overall percentage of parasitic infections among the studied school children (table 1) was $38.5 \%$. By species, the rate for Entamoeba histolytica was 20.4\%, Enterobius vermicularis 16.6\%, Giardia lamblia $15.2 \%$, H. nana $14.9 \%$, Ascaris lumbricoides 6.5\%, S. haematobium 5.7\%, Ancylostoma duodenale $5.1 \%$ and Trichuris trichiura 2.1. Mixed infections constituted $12.7 \%$.

As regard sociodemographic risk factors (table 2), the low level of paternal education (illiterate and read \& write), low level of paternal occupation (unskilled labor) and low social class were significant risk factors for parasitic infections $(\mathrm{OR}=$ 2.86, 95\% CI: 2.08-3.93; OR=3.27, 95\% CI: $2.31-4.61$ and $\mathrm{OR}=2.86$, 95\% CI: $2.06-$ 3.97 , respectively).

In respect life style and health care behavior risk factors (table 3); the improper hygienic food handling, poor personal hygiene, delayed consultation for treatment and incompliance with therapy were risk factors $(\mathrm{OR}=2.10,95 \%$ CI: 1.42-3.09; $\mathrm{OR}=2.63,95 \%$ CI: $1.85-3.74 ; \mathrm{OR}=10.83$, 95\% CI: 7.33-16.05 and OR=1.07, 95\% CI: 0.78-1.47, respectively). Also, no sibling's referral for treatment was risk factor $(\mathrm{OR}=2.14$, 95\% CI: 1.43-3.19). Water contact activities were risk factor, $(\mathrm{OR}=$ 1.90, 95\% CI: $1.38-2.61$ ).

In respect of personal characteristics risk factors (table 4); small age groups 6-8 years, male sex and the last birth child were risk factors $(\mathrm{OR}=1.12,95 \%$ CI: 0.82-1.52; $\mathrm{OR}=1.41,95 \% \mathrm{CI}: 1.05-1.91$ and $\mathrm{OR}=2.32$, 95\% CI: 1.76-3.23, respectively). Also the following represent significant risk factors; student having $\geq 4$ siblings ( $O R=1.39,95 \%$ CI: 1.02-1.90), having crowding index $>4$ $(\mathrm{OR}=1.45$, 95\% CI: 1.06-1.98), having houses with bad sanitary conditions $(\mathrm{OR}=1.94$, 95\% CI: 1.40-2.67), students with $1-2$ and $\geq 3$ infected siblings $(\mathrm{OR}=1.51,95 \% \mathrm{CI}: 1.11-2.04$ and $\mathrm{OR}=$ 4.17, 95\% CI: $2.80-6.23$, respectively) and having previous parasitic infections $\mathrm{OR}=$ 9.80, 95\% CI: 4.01-24.80. While, students with no infected sibling represent a significant protective factor $(\mathrm{OR}=0.20,95 \%$ CI: 0.14-0.28).

As regard the clinical characteristics and impacts of parasitic infections (table 5), $60.3 \%, 52.4 \%, 51.9 \%, 45.4 \%, 34.3 \%$, $32.7 \%, 28.4 \%, 26.5 \%, 21.4 \%$ and $2.4 \%$ of the students with positive parasitic infections suffered from headache, fatigue, pallor, loss of appetite, abdominal pain/colic, polyphagia, pruritus ani, fever, diarrhea and hematuria, respectively. These figures were significantly higher than those with negative parasitic infections. In respect to weight-for-age and height-for-age, $29.2 \%$ and $31.6 \%$, respectively of positive parasitic infection students were $<5^{\text {th }}$ percentiles compared with $17.6 \%$ and $3.0 \%$, respectively of negative parasitic infections. These differences are statistically significant. Anemic students with positive parasitic infections $(52.4 \%)$ were significantly higher than those with negative infections $(32.7 \%)$. In respect to scholastic achievement, $34.3 \%$ and $21.9 \%$ of positive and negative parasitic infection students respectively had results of the first term exam $<50.0 \% \quad(\mathrm{P}=0.00)$. Lastly, hepatomegaly was detected clinically in $3.2 \%$ and $0.8 \%$ of positive and negative parasitic infections, respectively. However, by ultra-sonography no case of periportal fibrosis (PPF), splenomegaly, bladder wall lesions or obstructive uropathy was detected in cases with hepatomegaly and/or schistosomiasis. 
Table (1): Distribution of parasitic infections among the studied school children.

\begin{tabular}{|l|c|c|}
\hline Parasitic infection & No. $(\mathbf{n = 9 6 0 )}$ & Percent \\
\hline Entamoeba histolytica & 196 & 20.4 \\
\hline Enterobius vermicularis (worm/ova) & 159 & 16.6 \\
\hline Giardia lamblia (cyst) & 146 & 15.2 \\
\hline Hymenolepis (H) nana (ova) & 143 & 14.9 \\
\hline Ascaris lumbricoides (ova) & 62 & 6.5 \\
\hline S. haematobium (ova) & 55 & 5.7 \\
\hline Ancylostoma duodenale (ova) & 49 & 5.1 \\
\hline Trichuris trichiura (ova) & 20 & 2.1 \\
\hline Mixed infection & 122 & 12.7 \\
\hline Total & 370 & 38.5 \\
\hline
\end{tabular}

Table (2): Distribution of positive and negative parasitic infection in students according to sociodemographic risk factors.

\begin{tabular}{|l|c|c|c|c|c|}
\hline \multirow{2}{*}{$\begin{array}{c}\text { Sociodemographic } \\
\text { risk factors }\end{array}$} & \multicolumn{2}{c|}{$\begin{array}{c}\text { Positive } \\
\text { cases (n=370) }\end{array}$} & \multicolumn{2}{c|}{$\begin{array}{c}\text { Negative } \\
\text { cases (n=370) }\end{array}$} & \multirow{2}{*}{ OR (95\% CI) } \\
\cline { 2 - 5 } & No. & $\mathbf{\%}$ & No. & \% & \\
\hline Paternal educational level: & & & & & \\
$\quad$ Illiterate, read \& write & 267 & 72.1 & 176 & 47.6 & $2.86(2.08-3.93)$ \\
Elementary & 72 & 19.5 & 119 & 32.2 & $0.51(0.36-0.72)$ \\
Secondary \& university & 31 & 8.4 & 75 & 20.2 & $0.36(0.22-0.57)$ \\
\hline Paternal occupational level: & & & & & \\
Unskilled & 300 & 81.1 & 210 & 56.8 & $3.27(2.31-4.61)$ \\
Semi-skilled \& skilled & 54 & 14.5 & 106 & 28.6 & $0.43(0.29-0.62)$ \\
Professional & 16 & 4.4 & 54 & 14.6 & $0.26(0.14-0.49)$ \\
\hline Social level: & & & & & \\
Low & 283 & 76.5 & 197 & 53.3 & $2.86(2.06-3.97)$ \\
Middle & 62 & 16.8 & 107 & 28.9 & $0.49(0.34-0.72)$ \\
High & 25 & 6.7 & 66 & 17.8 & $0.33(0.20-0.56)$ \\
\hline
\end{tabular}

Table (3): Distribution of positive and negative parasitic infection among students according to life style and health care behavior risk factors.

\begin{tabular}{|c|c|c|c|c|c|}
\hline \multirow{2}{*}{$\begin{array}{l}\text { Life style and health } \\
\text { care behavior risk factors }\end{array}$} & \multicolumn{2}{|c|}{$\begin{array}{c}\text { Positive } \\
\text { cases }(n=370)\end{array}$} & \multicolumn{2}{|c|}{$\begin{array}{c}\text { Negative } \\
\text { cases }(n=370))\end{array}$} & \multirow{2}{*}{$\begin{array}{l}\text { Odds Ratio (OR) } \\
\quad(95 \% \text { CI) }\end{array}$} \\
\hline & No. & $\%$ & No. & $\%$ & \\
\hline $\begin{array}{l}\text { Follow hygienic measures in food handling: } \\
\text { Yes } \\
\text { No }\end{array}$ & $\begin{array}{c}274 \\
96\end{array}$ & $\begin{array}{l}74.1 \\
25.9\end{array}$ & $\begin{array}{c}317 \\
53\end{array}$ & $\begin{array}{l}85.7 \\
14.3\end{array}$ & $\begin{array}{l}0.48(0.32-0.70) \\
2.10(1.42-3.09)\end{array}$ \\
\hline $\begin{array}{l}\text { Personal hygiene: } \\
\text { Good } \\
\text { Poor }\end{array}$ & $\begin{array}{l}234 \\
136 \\
\end{array}$ & $\begin{array}{l}63.2 \\
36.8 \\
\end{array}$ & $\begin{array}{c}303 \\
67\end{array}$ & $\begin{array}{l}81.9 \\
18.1\end{array}$ & $\begin{array}{l}0.38(0.27-0.54) \\
2.63(1.85-3.74)\end{array}$ \\
\hline $\begin{array}{l}\text { Water contact activities: } \\
\text { Yes } \\
\text { No }\end{array}$ & $\begin{array}{l}264 \\
106\end{array}$ & $\begin{array}{l}71.4 \\
28.6\end{array}$ & $\begin{array}{l}210 \\
160\end{array}$ & $\begin{array}{l}56.8 \\
43.2\end{array}$ & $\begin{array}{l}1.90(1.38-2.61) \\
0.53(0.38-0.27)\end{array}$ \\
\hline $\begin{array}{l}\text { Early consultation for treatment: } \\
\text { Yes } \\
\text { No }\end{array}$ & $\begin{array}{l}148 \\
222 \\
\end{array}$ & $\begin{array}{l}40.0 \\
60.0 \\
\end{array}$ & $\begin{array}{c}325 \\
45 \\
\end{array}$ & $\begin{array}{l}87.8 \\
12.2 \\
\end{array}$ & $\begin{array}{c}0.09(0.06-0.14) \\
10.83(7.33-16.05) \\
\end{array}$ \\
\hline $\begin{array}{l}\text { Compliance with therapy: } \\
\text { Yes } \\
\text { No }\end{array}$ & $\begin{array}{l}126 \\
244 \\
\end{array}$ & $\begin{array}{l}34.1 \\
65.9 \\
\end{array}$ & $\begin{array}{l}132 \\
238 \\
\end{array}$ & $\begin{array}{l}35.7 \\
64.3\end{array}$ & $\begin{array}{l}0.93(0.68-1.27) \\
1.07(0.78-1.47) \\
\end{array}$ \\
\hline $\begin{array}{l}\text { Sibling referral for therapy: } \\
\text { Yes } \\
\text { No }\end{array}$ & $\begin{array}{c}49 \\
321\end{array}$ & $\begin{array}{l}13.2 \\
86.8\end{array}$ & $\begin{array}{c}91 \\
279\end{array}$ & $\begin{array}{l}24.6 \\
75.4\end{array}$ & $\begin{array}{l}0.47(0.31-0.70) \\
2.14(1.43-3.19)\end{array}$ \\
\hline
\end{tabular}


Table (4): Distribution of positive and negative parasitic infection in students according to personal characteristics risk factors.

\begin{tabular}{|c|c|c|c|c|c|}
\hline \multirow[t]{2}{*}{ General characteristics } & \multicolumn{2}{|c|}{$\begin{array}{c}\text { Positive cases } \\
(\mathbf{n}=\mathbf{3 7 0})\end{array}$} & \multicolumn{2}{|c|}{$\begin{array}{c}\text { Negative cases } \\
\quad(\mathbf{n}=\mathbf{3 7 0})\end{array}$} & \multirow[t]{2}{*}{ OR $(95 \% \mathrm{CI})$} \\
\hline & No. & $\%$ & No. & $\%$ & \\
\hline \multicolumn{6}{|l|}{ Age: } \\
\hline 6-8 & 154 & 41.6 & 144 & 38.9 & $1.12(0.82-1.52)$ \\
\hline $9-11$ & 124 & 33.5 & 119 & 32.2 & $1.06(0.77-1.46)$ \\
\hline $12-16$ & 92 & 24.9 & 107 & 28.9 & $0.39(0.28-0.53)$ \\
\hline \multicolumn{6}{|l|}{ Sex: } \\
\hline Male & 203 & 54.9 & 171 & 46.2 & $1.41(1.05-1.91)$ \\
\hline Female & 167 & 45.1 & 199 & 53.8 & $0.71(0.52-0.95)$ \\
\hline \multicolumn{6}{|l|}{ Birth order: } \\
\hline First & 100 & 27.0 & 178 & 48.1 & $0.40(0.29-0.55)$ \\
\hline In the middle & 116 & 31.4 & 105 & 28.4 & $1.15(0.83-1.60)$ \\
\hline Last & 154 & 41.6 & 87 & 23.5 & $2.32(1.67-3.23)$ \\
\hline \multicolumn{6}{|l|}{ Number of siblings: } \\
\hline $0-1$ & 87 & 23.5 & 134 & 36.2 & $0.54(0.39-0.76)$ \\
\hline $2-3$ & 127 & 34.3 & 109 & 29.5 & $1.25(0.91-1.73)$ \\
\hline$\geq 4$ & 156 & 42.2 & 127 & 34.3 & $1.39(1.02-1.90)$ \\
\hline \multicolumn{6}{|l|}{ Crowding index: } \\
\hline$<2$ & 91 & 24.6 & 138 & 37.3 & $0.55(0.39-0.76)$ \\
\hline $2-4$ & 127 & 34.3 & 112 & 30.3 & $1.20(0.87-1.66)$ \\
\hline$>4$ & 152 & 41.1 & 120 & 32.4 & $1.45(1.06-1.98)$ \\
\hline \multicolumn{6}{|l|}{ Housing sanitary conditions: } \\
\hline $\mathrm{Bad}$ & 152 & 41.1 & 98 & 26.5 & $1.94(1.40-2.67)$ \\
\hline Fair & 135 & 36.5 & 154 & 41.6 & $0.81(0.59-1.10)$ \\
\hline Good & 83 & 22.4 & 118 & 31.9 & $0.62(0.44-0.87)$ \\
\hline \multicolumn{6}{|l|}{ Previous parasitic infections: } \\
\hline Yes & 255 & 68.9 & 107 & 28.9 & $9.80(4.01-24.80)$ \\
\hline No & 115 & 31.1 & 263 & 71.1 & $0.10(0.04-0.25)$ \\
\hline \multicolumn{6}{|l|}{ Number of infected siblings: } \\
\hline 0 & 61 & 16.5 & 186 & 50.3 & $0.20(0.14-0.28)$ \\
\hline $1-2$ & 178 & 48.1 & 141 & 38.1 & $1.51(1.11-2.04)$ \\
\hline$\geq 3$ & 131 & 35.4 & 43 & 11.6 & $4.17(2.80-6.23)$ \\
\hline
\end{tabular}




\section{H. M. El-Masry et al}

Table (5): Distribution of positive and negative parasitic infections in students according to clinical characteristics and impacts.

\begin{tabular}{|c|c|c|c|c|c|c|}
\hline \multirow{2}{*}{$\begin{array}{c}\text { Clinical characteristics } \\
\text { and impacts }\end{array}$} & \multicolumn{2}{|c|}{$\begin{array}{c}\text { Positive cases } \\
(n=370)\end{array}$} & \multicolumn{2}{|c|}{$\begin{array}{c}\text { Negative cases } \\
(\mathbf{n}=370)\end{array}$} & \multirow[t]{2}{*}{$\chi^{2}$} & \multirow[t]{2}{*}{ P-value } \\
\hline & No. & $\%$ & No. & $\%$ & & \\
\hline \multicolumn{7}{|l|}{ Complaint: } \\
\hline Headache & 223 & 60.3 & 83 & 22.4 & 109.2 & 0.000 \\
\hline Fatigue & 194 & 52.4 & 94 & 25.4 & 56.85 & 0.000 \\
\hline Pallor & 192 & 51.9 & 66 & 17.8 & 94.47 & 0.000 \\
\hline Loss of appetite & 168 & 45.4 & 79 & 21.4 & 48.14 & 0.000 \\
\hline Abdominal pain/colic & 127 & 34.3 & 57 & 15.4 & 34.44 & 0.000 \\
\hline Polyphagia & 121 & 32.7 & 45 & 12.2 & 44.86 & 0.000 \\
\hline Pruritus ani & 105 & 28.4 & 56 & 15.1 & 19.06 & 0.000 \\
\hline Fever & 98 & 26.5 & 71 & 19.2 & 14.46 & 0.000 \\
\hline Diarrhea & 79 & 21.4 & 49 & 13.2 & 8.50 & 0.004 \\
\hline \multicolumn{7}{|l|}{ Weight-for-age: } \\
\hline $\begin{array}{l}<5^{\text {th }} \text { percentile } \\
5^{\text {th }}-95^{\text {th }} \text { percentile }\end{array}$ & $\begin{array}{l}108 \\
251\end{array}$ & $\begin{array}{l}29.2 \\
67.8\end{array}$ & $\begin{array}{l}65 \\
289\end{array}$ & $\begin{array}{l}17.6 \\
78.1\end{array}$ & $\begin{array}{l}13.95 \\
9.89\end{array}$ & $\begin{array}{l}0.000 \\
0.001\end{array}$ \\
\hline$>95^{\text {th }}$ percentile & 11 & 3.0 & $\begin{array}{l}203 \\
16\end{array}$ & 4.3 & $\begin{array}{l}.09 \\
0.96\end{array}$ & 0.433 \\
\hline \multicolumn{7}{|l|}{ Height-for-age: } \\
\hline$<5^{\text {th }}$ percentile & 117 & 31.6 & 69 & 18.7 & 16.55 & 0.000 \\
\hline $5^{\text {th }}-95^{\text {th }}$ percentile & 242 & 65.4 & 271 & 73.2 & 5.34 & 0.021 \\
\hline$>95^{\text {th }}$ percentile & 11 & 3.0 & 30 & 8.1 & 9.32 & 0.002 \\
\hline \multicolumn{7}{|l|}{ Hematuria: } \\
\hline Yes & 9 & 2.4 & 1 & 0.3 & & \\
\hline \multirow{2}{*}{\multicolumn{7}{|c|}{ Anemia: }} \\
\hline & & & & & & \\
\hline Yes & 194 & 52.4 & 121 & 32.7 & & \\
\hline No & 176 & 47.6 & 249 & 67.3 & 28.65 & 0.000 \\
\hline \multicolumn{7}{|l|}{ Hepatomegaly: } \\
\hline Yes & 12 & 3.2 & 3 & 0.8 & & \\
\hline No & 358 & 96.8 & 367 & 99.2 & 4.35 & 0.036 \\
\hline \multicolumn{7}{|l|}{ School absenteeism: } \\
\hline $0-3$ day/month & 152 & 41.1 & 194 & 52.4 & 9.12 & 0.003 \\
\hline 4-6 days/month & 140 & 37.8 & 112 & 30.3 & 4.39 & 0.036 \\
\hline$\geq 7$ days/month & 78 & 21.1 & 64 & 17.3 & 1.47 & 0.225 \\
\hline \multicolumn{7}{|l|}{ Scholastic achievement: } \\
\hline$\geq 85.0 \%$ & 81 & 21.9 & 102 & 27.6 & 3.20 & 0.074 \\
\hline$\geq 65.0 \%$ & 54 & 14.6 & 66 & 17.8 & 1.43 & 0.231 \\
\hline$\geq 50.0 \%$ & 108 & 29.2 & 121 & 32.7 & 1.07 & 0.301 \\
\hline$<50.0 \%$ & 127 & 34.3 & 81 & 21.9 & 14.15 & 0.000 \\
\hline
\end{tabular}

\section{Discussion}

As regard distribution of parasitic infections among the studied school children (table 1), the overall percentage of parasitic infections was $38.5 \%$. This was similar to El-Gammal et al. (1995) who reported that the prevalence of parasitic infection among Egyptian school children in Malames village in Lower Egypt was $31.9 \%$. However, our result was less than that reported in Upper Egypt by Shalaby et al. (1986) and El-Gammal et al. (1995) who reported that the prevalence of parasitic infections among Egyptian school children in Tamouh and Demo villages were $60.2 \%$ and $88.5 \%$, respectively. Rim et al. (2003) collected 29,846 stool specimens from primary school children in Laos and the cumulative egg positive rate for intestinal helminthes was $61.9 \%$.

Pathogenic intestinal protozoan parasites include five groups: the flagellates (Giardia lamblia and Dientamoeba fragilis); the amebae, or Sarcodina (Entamoeba histolytica and, possibly, 
Blastocystis hominis); coccidia (Cryptosporidium, Isospora, Cyclospora); a ciliate (Balantidium coli) and microsporidia (Voorhis and Weller 2002). An estimated $10.0 \%$ of the world's population is infected with $E$. histolytica; the highest prevalence is in developing countries with the lowest levels of sanitation. $G$ lamblia is the most commonly isolated intestinal parasite throughout the world. Rates of 20.0-40.0\% are reported in developing countries, especially in children (Chacon-Cruz and Mitchell, 2007). In this study E. histolytica and G. lamblia were reported in $20.4 \%$ and $15.2 \%$ respectively and no evidence of other protozoa. Mahmoud (1983) agreed with our result. Also, Oluwafemi (2003) reported that prevalence of E. histolytica was $24.0 \%$. Rashid et al. (2002) reported similar result as regard $G$. lamblia. While, El-Gammal et al. (1995) reported 5.4\% and $8.9 \%$ prevalence of E. histolytica and $G$. lamblia, respectively. Kandeel (1998) found that prevalence of E. histolytica and G. lamblia in school children in rural areas of Qalubia was $39.5 \%$ and $2.2 \%$, respectively. Ungar (1990) reported a two fold prevalence of $G$. lamblia $(30.0 \%)$. Because infection derives from fecally excreted organisms and is spread by direct fecal-oral passage or by food borne or water borne transmission (Voorhis and Weller, 2002), these differences of prevalence in different locations may be attributed to different levels of sanitation, types of water supply, hygienic measures and food behaviors.

Enterobius vermicularis is a nematode and has the broadest geographic range of any helminthes. Since the first evidence of pin worm infection from Roman-occupied Egypt (Horne 2002), it has been known to be the most common intestinal parasite seen in the primary care setting (Petro et al., 2005). H. nana is the smallest tape worm that infects humans. This parasite has worldwide distribution (Ismail et al., 2007). Children between the ages of 4 and 10 years are the most frequently affected (Macariola et al., 2002). Both E. vermicularis $(16.6 \%)$ and $H$. nana (14.9\%) represented the highest prevalence of nematode and cestode infections, respec-tively in this study. Both characterized by transmission secondary to contamination of the hands and can cause autoinfection denoting the role of personal hygiene and contact with infected individuals either in the school or within their families. In school children in rural areas of Qalubia, Kandeel (1998) found that prevalence of Enterobius vermicularis and $H$. nana were $3.5 \%$ and $5.8 \%$, respectively. While, El-Gammal et al. (1995) reported $40.4 \%$ prevalence of Enterobius vermicularis. Also, a survey, in Laos, by cellophane anal swab detected Enterobius vermicularis eggs in $35.7 \%$ of school children aged 6-8 years (Rim et al., 2003).

Infection with intestinal round worms constitutes the largest group of helminthic infections in humans worldwide (Hökelek and Lutwick, 2006). STH is widespread in most poverty-stricken areas in the developing world; it affects more than 2000 million people worldwide. STH caused by infection with the nematodes; Ascaris lumbricoides (round worm), Ancylostoma duodenale and Necator americanus (hook worm) and Trichuris trichiura (whip worm) (WHO, 2006). Infection is caused by ingestion of eggs from contaminated soil (Ascaris lumbricoides and T. trichiura) or by active penetration of the skin by larvae in the soil (hook worms) (Crompton and Savioli, 2006). In this study, the rate for Ascaris lumbricoides was $6.5 \%$, Ancylostoma duodenale $5.1 \%$ and $T$. trichiura 2.1\%. El-Gammal et al. (1995) found that prevalence of Ascaris lumbricoides was $6.3 \%$ and Ancylostoma duodenale was $1.9 \%$. Kandeel (1998) found that Trichuris trichiura had the lowest percentage, $2.1 \%$, in his study. Our result was lower than that of Lindo et al. (2002) who reported that prevalence of Ascaris lumbricoides was $18.8 \%$, and Rim et al. (2003) who showed a higher prevalence (>70\%) of STH; by species, the rate for Ascaris lumbricoides was $34.9 \%$, hook worm $19.1 \%$ and T. trichiura $25.8 \%$.

Schistosomiasis is an endemic disease in Egypt (El-Khoby et al., 2000) and it constitutes a major health problem (AbdelWahab and Mahmoud, 1987). In the present study the prevalence of $S$. haematobium infection as determined by ova in the urine was $5.7 \%$. Similar results were reported by recent studies in many governorates in Upper Egypt; the overall estimated 


\section{H. M. El-Masry et al}

prevalence of S. haematobium in Assuit Governorate was $5.21 \%$ (Hammam et al., 2000a), Qena Governorate $4.8 \pm 0.7 \%$ (Hammam et al., 2000b) and Minya 8.8\% (Gaber et al., 2000). Although there was variation in prevalence of $S$. haematobium between these governorates, the highest prevalence was lower than figures reported by independent researchers as recently as 1982. At that time, some villages had prevalence estimates in excess of $60.0 \%$ (King et al., 1982). Kitron and Higashi (1985) noted that among the most intensely infected male school children, infection rates were decreasing sharply at every 6month follow-up of their cohort. Webbe and El Hak (1990) stated that by 1988, the prevalence had decreased to $10.3 \%$. Our result supported that of Hammam et al. (2000b) and suggested that the prevalence has continued to decrease to about half of the 1988 level denoting the success of National Bilharzia Control Program in Upper Egypt. The general decline in schistosomiasis rates in Egypt in recent decades is in contrast to the situation in most other African countries where rates have increased, apparently due to the intensive schistosomiasis control and water supply programs (Bergquist, 1998). Also, our result, as regard prevalence of $S$. haematobium were less than El-Gammal et al. (1995) (22.4\%), El-Hak (1987) (6.2\% in Delta, $7.8 \%$ in Middle Egypt and $11.0 \%$ in Upper Egypt) and El-Hawy et al. (1990) who found that $19.3 \%$ of rural children were infected by $S$. haematobium. These differences could be due to the different circumstances in period, place, main irrigation systems and the progress of mass treatment against schistosomiasis at national level.

At the same time, mixed infection constitutes $12.7 \%$. Trichuriasis often occurs concurrently with hock worm infections and so may well accelerate the onset of iron-deficiency anemia (WHO, 2002). G. lamblia infection, Dientamoeba fragilis trophozoites and $H$. nana ova were identified in the same individual (Macariola et al., 2002).

As regard sociodemographic risk factors (table 2), we showed that the low level of paternal education, low level of paternal occupation (unskilled labor) and low social class were significant risk factors for parasitic infections. These were in accordance with El-Gammal et al. (1995) who reported that $43.0 \%$ of their students were belonging to low socioeconomic standard in Lower Egypt. Also, parasitic infections were more common in rural areas and among lower socioeconomic groups (Mahmoud, 1983 and Markell et al., 1999).

As regard life style and health care behavior risk factors (table 3), we cleared that the improper hygienic measures in food handling, poor personal hygiene, water contact activities delayed consultation for treatment, incompliance with therapy and no sibling's referral for treatment were risk factors. Mahmoud (1983) agreed with our results in that poor personal hygiene encourages person-to-person transmission, and also poor food handling hygienic measures, presence of flies and cockroaches as vectors of transmission of infection and contaminated water encourage transmission. Water contact activities represented significant risk (Farag et al., 1993). Children playing or swimming in canals had significant rate of infection and morbidity by $S$. haematobium (Hammam et al., 2000b).

In respect of distribution of positive and negative parasitic infection students according to personal characteristics risk factors (table 4), we noticed that small age groups 6-8 and 9-12 years were risk factors. This was in agreement with Mahmoud (1983), Farag et al. (1993) and Demetrio et al. (2002), and comparable to that of Yassin et al. (1999) who cleared that infection with G. lamblia was more common among young children. At the same time, male sex was found a risk factor. This is in agreement with Farag et al. (1993) and Hammam et al. (2000b) who cleared that schistosomiasis was more common among boys; this might be due to more contact with polluted water. While, Oluwafemi (2003) showed that some parasitic infections as $E$. histolytica was higher in girls than boys, and some parasitic infections as Ascaris was higher in boys than girls. Moreover, the last birth child, student having $\geq 4$ siblings, a student having crowding index $>4$ and bad housing sanitary conditions were found significant risk factors. In general, parasitic infections 
are more prevalent under crowded conditions (Markell et al., 1999). The prevalence, severity and incidence of complications of most enteric parasitic infections vary inversely with the level of sanitary conditions. They are more common in rural areas (Markell et al., 1999). STH is widespread in most poverty-stricken areas in the developing world (WHO, 2006). Also, our results are in accordance with Mahmoud (1983) and Gamboa et al. (1998) who cleared that intestinal parasites are transmitted directly through the contaminated water, soil and food by feces, or indirectly through unsanitary living conditions.

As regard the clinical characteristics and impacts of parasitic infections (table 5), $60.3 \%, 52.4 \%, 51.9 \%, 45.4 \%, 34.3 \%$, $32.7 \%, 28.4 \%, 21.4 \%$ and $2.4 \%$ of students with positive parasitic infections suffered from headache, fatigue, pallor, loss of appetite, abdominal pain/colic, polyphagia, pruritus ani, diarrhea and hematuria, respectively. These figures are significantly higher than those with negative parasitic infections. Intestinal invasion may be asymptomatic (small number) or presented by various symptoms as abdominal pain (usually vague), abdominal cramps/colic, diarrhea, vomiting (rarely) and constipation (occasionally). However, the most common symptom in pin worm infection is nocturnal perianal pruritus (Hökelek and Lutwick, 2006). Most of the parasitic infections causing acute or chronic diarrhea with mal absorption (Mahmoud, 1983 and Alberton et al., 1995). The most frequent associating symptoms were diarrhea and distension (Mahmoud, 1983 and Current \& Garcia, 1991). However, chronic symptoms such as dyspepsia, epigastric pain, nausea and anorexia may be present (Mahmoud, 1983; Addis et al., 1992 and Fayad et al., 1992). El-Hawy et al. (1992) and Markel et al. (1999) cleared that, through effect on the intestinal flora, children infected with enteric parasites may suffer from colitis that lead to vague, non-specific abdominal symptoms. So, they usually lose their food interest to prevent these symptoms. Hematuria was significant presenting finding among those infected by $S$. haematobium (Hammam et al., 2000a \&b and El-Khoby et al., 2000).
In respect to weight-for-age and height-forage, $29.2 \%$ and $31.6 \%$, respectively of positive parasitic infection students were $<5^{\text {th }}$ percentiles compared with $17.6 \%$ and $3.0 \%$, respectively of negative parasitic infection. Also, anemic students (52.4\%) with positive parasitic infections were significantly higher than those with negative infection $(32.7 \%)$. These findings were in accordance with Casap Ãa et al. (2006) and WHO/WER (2006). Our results were expected, as parasitic infections are thought to contribute to child malnutrition, micronutrient deficiency and protein loss through subtle reduction in digestion and absorption, chronic inflammation and loss of nutrients. Childhood is the time of intense growth; it is the period in which the velocity of individual's growth had a rapid increase (Abdel-Rahman, 1988; Heald \& Gong, 1999 and Rees et al., 1999). Parasites may decrease food intake, loss of appetite, the maintenance of nutrient pools and anemia secondary to blood loss (ElHawy et al., 1992 and Hesham et al., 2004). So, impairment of the anthropometric measures and anemia were more prevalent among these children. About $43.0 \%$ of children in developing countries were stunted and 9.0\% were wasted (DeOnis and Habicht, 1996). In Egypt, during 1995$2002,11.0 \%, 5.0 \%$ and $21.0 \%$ of children were suffering from underweight, wasting and stunting, respectively (UNICEF, 2004). Our results were in accordance with Khalil (1982) and Shalabi (1991) who showed that enteric parasitic infections had significant effect on weight and height. Also, ElBaroudy et al. (1993) observed that Giardia infection might lead to impairment in anthropometric measures of the infected children. On the other hand, Kandeel (1998) did not find any effect of parasitic infections on children growth, but he attributed this to the recent, light intensity of infection or infection for a short period. Also, Shalaby et al. (1986); El-Shobaki et al. (1990); Hassan (1990); Rozeik and ElMoselhy (1997); WHO (1998) and WHO/WER (2006) cleared that parasitic infections were commonly associated with anemia.

Regarding school absenteeism, 37.8\% and $41.1 \%$ of positive parasitic infection students had 0-3 and 4-6 days/month 


\section{H. M. El-Masry et al}

absent, respectively. WHO (2002) stated that no doubt that poor iron status and irondeficiency anemia are closely linked to diminished educational performance. Absenteeism was more frequent among infected than uninfected children. El-Hawy et al. (1990) and Rozeik \& El-Moselhy (1997) noted higher incidence of absenteeism rate among their rural bilharzial groups. In respect to scholastic achievement, $34.3 \%$ and $21.9 \%$ of positive and negative parasitic infection students respectively had results of the first term exam $<50.0 \%$. About 400 million school children infected with parasites are often physically and intellectually compromised by anemia, leading to attention deficits, learning disabilities, school absenteeism and higher dropout rates (WHO/WER, 2006). Moreover, our result was in accordance with Khalil (1982); El-Hawy et al. (1990); Kimura et al. (1992); Rozeik \& El-Moselhy (1997) and Steinmann et al. (2006) who observed marked increase in examination failure rate among their bilharzial groups. This might be attributed to anemia and malnutrition (Khalil, 1982; El-Shobaki et al., 1990; Hassan, 1990 and WHO/WER, 2006). Iron deficiency anemia lowers resistance to disease and weakens a child's learning ability and physical stamina. Many factors cause iron deficiency anemia including inadequate diet, blood loss and parasitic infections as hook worm (WHO, 1998 and WHO/WER, 2006).

Hepatomegaly was detected clinically and by ultra-sonography in $3.2 \%$ of positive parasitic infections versus $0.8 \%$ of negative parasitic infections. This result is in agreement with Rozeik and El-Moselhy (1997). However, no case of PPF, splenomegaly, urinary bladder wall lesions or obstructive uropathy was detected. These may be attributed to the absence of $S$. mansoni infection and more or less early infections of young students. Urinary bladder lesions and liver PPF, which can be determined only by ultra-sonography, were very infrequent and present only in adults (Hammam et al., 2000a\&b).

\section{Conclusion And Recommendations}

We can conclude that $38.5 \%$ of rural students were infected with parasites and
$29.2 \%$ and $31.6 \%$ of them were $<5^{\text {th }}$ percentiles as regard weight -and heightfor-age, respectively. Also, $52.4 \%$ of students were anemic. The most important risk factors, which affect the prevalence of parasitic infections, were low socioeconomic level, high number of infected siblings, previous parasitic infections and no early consultation for therapy. Parasitic infections had a significant negative impact on scholastic absenteeism and achievement of the infected students. We recommend improving personal and environmental hygienic measures, regular screening and treatment for parasitic infections and more studies on big number of students in rural and urban areas of Egypt. School health team with good equipment should be focused on and school health programs should be integrated in medical and nursing curriculums.

\section{References}

1. Abdel-Rahman AH (1988): Socioeco-nomic impacts of human schistosomiasis. M.D. Thesis in Tropical Medicine, Faculty of Medicine, Al-Azhar University.

2. Abdel-Wahab MF and Mahmoud SS (1987): Schistosomiasis in Egypt. Clin Trop Med Communic Dis., 2: 37195.

3. Addis DC, Davis JP, Roberts JM and Masty MM (1992): Epidemiology of Giardiasis in Wisconsin: Increasing incide-nce of reported cases and unexplained seas-onal trends. Am.J.Trop.Med. Hyg., 47: 13-9.

4. Alberton F, Newman CP and Casemore DP (1995): An outbreak of waterborne cryptosporidiosis associated with public water supply in UK. Epidemiol Infect., 115: 123-31.

5. Bergquist $R \quad$ (1998): Schistosomiasis in the world. Paper presented at the SRP 1998 International Conference on Schistos-omi-asis. The Schistosomiasis Research Project, Ministry of Health, Cairo, 15-19.

6. CasapẴa M, Joseph SA, $\mathbf{N}^{\circ}{ }^{\circ} \tilde{A} \pm$ ez $\quad C$, Rahme $\mathbf{E}$ and Gyorkos TW (2006): Parasite risk factors for stunting in grade 5 
students in a community of extreme poverty in Peru. Int $\mathrm{J}$ Parasitol, 36 (7): 741-7.

7. Chacon-Cruz $\mathbf{E}$ and Mitchell DK (2007): Intestinal protozoal diseases. $\quad \mathrm{http} / / / \mathrm{www}$. emedicine.com/ped/TOPIC1914.H TM

8. Crompton DWT and Savioli L (2006): Handbook of helminthiasis for public health. Boca Raton, Florida - Taylor and Francis Group, LLC.

9. Current WL and Garcia LS (1991): Cryptosporidiosis. Clin Microbial Rev., 3: 325-58.

10. Delgado $\mathbf{H}$, Plama $\mathbf{P}$ and Fischer M (1991): The use of the height census of school children in Central America and Panama. Food Nutr Bull., 13 (1): 17-29.

11. DeOnis $M$ and Habicht $J$ (1996): Anthropometric references data for international use: Recommendation from a WHO Expert Committee. Am J. Clin. Nutr, 64: 650-8.

12. El-Baroudy $R$, Sayed $M$ and Rashid S (1993): Interaction of multiple parasitic infections and nutrition. Med. J. Cairo University, 61 (3): 569-82.

13. El-Gammal N, Sayed El-Ahl S, Osman FH and Salem HS (1995): Comparative study of parasitic infections among school children in two rural areas in upper Egypt (Demo village) and lower Egypt (Malames village). The Egypt J Comm Med., 3 (1): 25-30.

14. El-Hak S (1987): Schistosomiasis in Egypt. National control programme on goi-ng projectsfuture policy. Schistosomiasis Symposium in Cairo.

15. El-Hawy AM, Wahib AA and Rozeik MS (1990): Impacts of schistosomiasis on scholastic achievement of school children in two Egyptian rural communities. The Egypt J Comm Med., 7 (2): 27-40.

16. El-Hawy AM, Abdel-Rahman MM, Rozeik MS, Rageb KH and Pypers M (1992): Study of physical fitness in adult bilharzial mansoni patient versus athletes. Menoufia Med. J., 4: 63-7.

17. El-Khoby T, Hussein MH, Galal $N$ and Miller ED (2000):
Epidemiology of schis-tosomiasis in Egypt: Summary findings in nine - 1, 2, 3: Origins, objectives, organiz-ation and implementation. Am. J. Trop. Med. Hyg., 62 (2): 2 7.

18. El-Shobaki FA, El-Hawary ZM and Salem NA (1990): Competing anemia am-ong school children using a highly available on preparation. The Egypt J. Comm Med., 7 (2): 81-94.

19. EI-Zanaty FH, Sayed SA and Way AA (2000): Nutritional status of children: Demographic and Health Survey, Egypt 2000, National Population Council, Cairo.

20. Farag O, Hafes $M$ and Kamel $M$ (1993): Morbidity from Schistosoma mansoni in an Egyptian village: A community based study. The Egypt J. Comm. Med., 11 (1): 125-33.

21. Fayad ME, El-Khattib AH, AbdElkader S and Sabry H (1992): Parasitic infections among children attending the gastroentrology clinic in King Faisal Hospital, Holy Mecca, Saudia Arabia. Sci Med. J. Cai. Synd., 4: 63-70.

22. Gaber NS, Hammad TA, Orieby A, Shawky E.Khatab MA and Strickland GT (2000): The Epidemiology of Schistos-omiasis in Egypt: Minya governorate. Am J. Trop. Med. Hyg., 62(2): 65-72.

23. Gamboa M, Basualdo J, Kozubusky L, Costas E and Cueto R (1998): Prevalence of intestinal parasitosis within the popul-ation groups in La Plata, Argentina. Eur. J. Epidemiol, 14: 55-61.

24. Garcia LS and Bruckner DA (1997): Diagnostic medical parasitology. Am Soc Microbiol. 7 (2): $30-40$

25. Gorstein J (1989): Assessment of nutriti-onal status: Effect of different methods to determine age on the classification of under nutrition. Bull WHO, 67: 143-50.

26. Habicht JP, Martorell R, Yarbrough C, Malina MR and Klin RE (1974): Height and weight standards for preschool children are there really ethnic 
differences in growth potentials? Lancet, 1: 1611-5.

27. Hammam HM, Sallam FA, Moftah FM, Abdel-Aty MA and Hany AH (2000a): The Epidemiology of Schistosomiasis in Egypt: Assuit Governorate. Am. J. Trop. Med. Hyg., 62(2): 73-9.

28. Hammam HM, Zarzour AH, Moftah FM, Abdel-Aty MA, Hany AH, El-Kady AY, Nasr AM, Abd-El-Samie A, Qayed MH, Mikhail NH, Talaat $M$ and Hussein MH (2000b): The Epidemiology of schist-osomiasis in Egypt: Qena Governorate. Am J Trop Med Hyg, 62(2): 80-7

29. Hassan YM (1990): Nutritional status and its relation to scholastic achievement in preschool and school children in Cairo. M.D. Thesis in Public Health, Faculty of Medicine, Al-Azhar University.

30. Heald FP and Gong EJ (1999): Diet, nutrition and adolescence. In: Modern nutrition in health and disease, Williams and Wilkins, Maryland, USA.

31. Hesham MS, Edariah AB and Norhayati M (2004): Intestinal parasitic infections and micronutrient deficiency. Med J Malaysia, 59 (2): 284-93.

32. Hökelek $M$ and Lutwick LI (2006): Nematode infections. Nematode infections. htm, eMedicine Specialties>Medicine, Ob/Gyn, Psychiatry, and Surgery> Infectious Diseases.

33. Horne PD (2002): First evidence of enterobiasis in ancient Egypt. J. Parasitol., 88:1019-21.

34. Ismail HI, Hamouda HE, Baalash AA, Haiba AA, Ismail GM and Shamloula MM (2007): Immunohistochemical and neurotransmitter changes in brain of mice infected with Hymenolopis nana. Tanta Med Sc. J., 2 (1): $117-$ 23.

35. Kafafi A and Abdel-Mottaleb AM (1992): Effects of socioeconomic standard on growth of school children in Cairo. AlAzhar Med. J., 21 (B): 53-64.

36. Kandeel A (1998): Assessment of growth pattern of Egyptian rural school children at Shebin AlKanater, Qalubia, Egypt. M.Sc.
Thesis in Public Health, Faculty of Medicine, Ain-Shams University.

37. Khalil SA (1982): Parasitic infection among school children and its impact on their growth and scholastic achievement in an Egyptian rural community. M.Sc. Thesis in Public Health, Faculty of Medicine, Al-Azhar University.

38. Kimura E, Moji K, Uga S, Kiliku F, Megwi D, Mutua W, Muhoho N and Aoki Y (1992): Effects of Schistosoma hematobium infection on mental test scores of Kenyan school children. Trop Med Parasitol., 43: 155-8.

39. King CL, Miller FD, Hussein M, Barkat R, Monto AS (1982): Prevalence and intensity of Schistosoma haematobium infection in six villages of Upper Egypt. Am J. Trop. Med. Hyg., 31: 320-7.

40. Kitron UD and Higashi GI (1985): Schistosoma haematobium in Upper Egypt: Analysis of dispersion patterns. Am J. Trop. Med . Hyg., 34: 331-40.

41. Lindo J, Validum $\mathbf{L}$ and Ager A (2002): Intestinal parasites among young children in the interior of Guyana. West Indian Med. J., 51 (1): 25-7.

42. Macariola DR, Jr Dee Daniels RN and Staat MA (2002): Intestinal parasites in an international adoptee. Infect Med 19 (1): 13-6.

43. Mahmoud AF (1983): Parasitic infections. In: Nelson textbook of pediatrics. WB Saunders Company, Philadelphia.

44. Markell EK, John DT and Krotoski WA (1999): Medical parasitology book. WB Saunders Publications, Philadelphia.

45. Michael GF (1997): This wormy world: Fifty years on. Parasitol Today, 13 (11): Poster insert.

46. Nesbitt RA, Mosha FW and Katki HA (2004): Amebiasis and comparison of micr-oscopy to ELISA technique in detection of Entamoeba histolytica and Entamoeba dispar. J. Natl. Med. Assoc., 96 (5): 671-7.

47. Peters PA, Alamy M, Warren KS and Mahmoud AF (1980): Quick Kato smear for field 
quantification of $S$. mansoni eggs. Am. J. Trop. Med. Hyg., 29: 217 19.

48. Petro M, Iavu $\mathbf{K}$ and Minocha A (2005): Unusual endoscopic and microscopic view of Enterobius Vermicularis. South Med. J., 98(9): 927-9.

49. Oluwafemi O (2003): Parasitic infestation and anemia: The prevalence in a rural hospital setting. J Indian Acad Clin Med., 4 (3): 281-7.

50. Rashid SM, Nagaty IM, Maboud AI, Fouad MA and Shebl A (2002): Comparative study on ELISA, IFA and direct methods in diagnosis of giardiasis. J. Egypt. Soc. Parasitol., 32 (2): 381-9.

51. Rees JM, Neumark-Sztainer D, Kohn $M$ and Jacobson $M$ (1999): Improving the nutritional health of adolescents- Position statement- Society for adolescent medicine. J. Adolescent Health, 24: 461-2.

52. Remme J (2007): Strategic emphases for tropical diseases research: A TDR perspective. Trends Parasitol., 18: 421-6.

53. Rim HJ, Chai JY, Min DY, Cho SY, Eom KS, Hong SJ, Sohn WM, Yong TS, Deodato G, Standgaard H, Phommasack B, Yun CH, Hoang EH (2003): Prevalence of intestinal parasite infections on a national scale among primary schoolchildren in Laos. Parasitol Res.,91(4):267-72.

54. Rozeik MS and El-Moselhy EA (1997): Effect of schistosomiasis on scholastic achievement of preparatory school children in two Egyptian villages. The Egypt J. Comm. Med., 18 (1): 1009-16.

55. Shalabi AN (1991): The effect of parasitic infestation on growth curve in pediatric age groups. M.Sc. Thesis in Pediatrics, Faculty of Medicine, Cairo University.

56. Shalaby S, Labib $\mathbf{N}$ and Amer $\mathbf{N}$ (1986): Epidemiological pattern and haematolo-gical findings of parasitic infestations in Egypt: Comparative study between rural and urban primary school children. The Egypt J. Comm. Med., 2 (1): 99-112.
57. Ismail HI, Hamouda HE, Baalash AA, Haiba AA Ismail GM and Shamloula MM (2007): Immunohisto-chemical and neurotransmitter changes in brain of mice infected with Hymenolopis nana. Tanta Med. Sc. J., (2), (1); 117-123.

58. Steinmann P, Keiser J, Bos R, Tanner $M$ and Utzinger $\mathbf{J}$ (2006): Schistosomiasis and water resources development: Systematic review, meta-analysis, and estimates of people at risk. The Lancet Infectious Diseases, 6: 411-425.

59. Ungar BLP (1990): Cryptosporidiosis in human. In: Cryptosporidiosis of man and animals. Boca Raton, Florida, CRC Press.

60. UNICEF (2000): Egypt demographic and health survey report. UNICEF Egypt.

61. UNICEF (2004): The state of the world's children 2004: Girls education and develo-pment. UNICEF Publication.

62. Van Den JB, Eeckels $R$ and Massa G (1996): Validity of single weight measur-ement to predict current nutritional status and mortality in children. British J Nutr., 126: 113-20.

63. Vaughan III VC (2004): Growth and development. In: Nelson textbook of pedia-trics. WB Saunders Company, Philadelphia.

64. Voorhis WC and Weller PF (2002): Protozoan infections: Intestinal protozoan infections.http://www.medscape.c om/viewarticle/534941.

65. Webbe G and El Hak S (1990): Progress in the control of schistosomiasis in Egypt 19851988. Trans R. Soc. Trop. Med. Hyg., 84: 394-400.

66. WHO (1995): Physical status: The use and interpretation of anthropometry. Report of a WHO Expert Committee. WHO Technical Report Series No. 854, Geneva., WHO.

67. WHO (1998): The state of the world's children: A UNICEF report. Nutrition Reviews, 56 (4): 115-23.

68. WHO (2001): Control of schistosomiasis and soil- 
H. M. El-Masry et al

transmitted helminthes infections: Report by the Secretariat, Executive Board $107^{\text {th }}$ session, Provisional agenda item 3.3 (EB107/31), Geneva, WHO.

69. WHO (2002): Prevention and control of schistosomiasis and soil-transmitted helmi-nthiasis: WHO Technical Report Series No. 912, Geneva, WHO.

70. WHO (2006): Preventive chemotherapy in human helminthiasis (Manual). World Health Organization, Preventive Chemot-herapy and Transmission Control (PCT), Department of Control of Neglected Tropical
Diseases (NTD), 1211 Geneva 27, Switzerland.

71. WHO/WER transmitted helminthes infections: Preliminary estimates of the number of children treated with albendazole or mebendazole. Weekly epidemiological record., 81 (16): 145-64.

72. Yassin MM, Shubair ME, AlHindy AI and Jadallah S (1999): Prevalence of intestinal parasites among school children in Gaza city. J Egypt Soc Parasitol., 29 (2): 365-73.

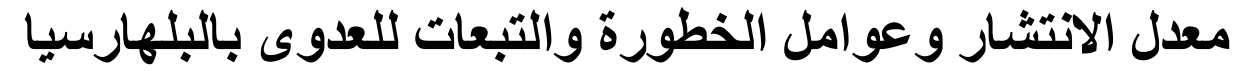 والطفيليات المعوية بين أطفال المدارس القروية في محافظة سوهاج}

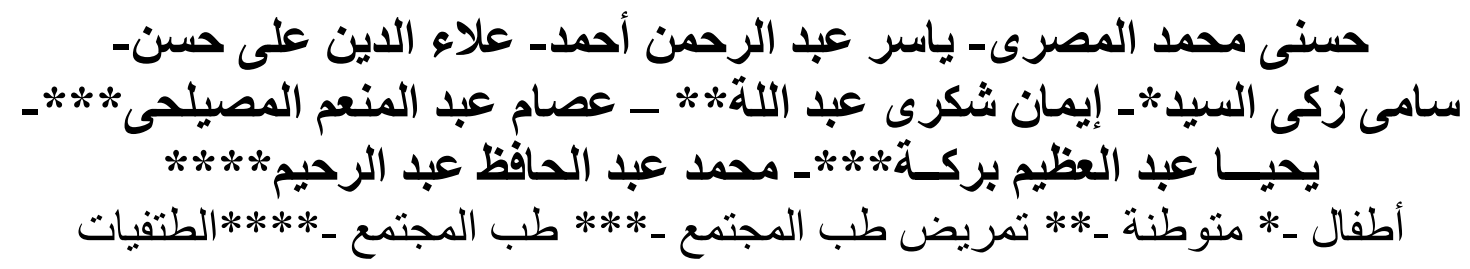


طب الأزهر - كلية التمريض جامعة الزقازيق

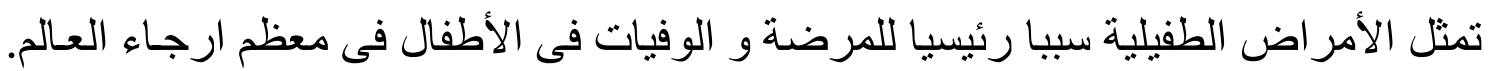

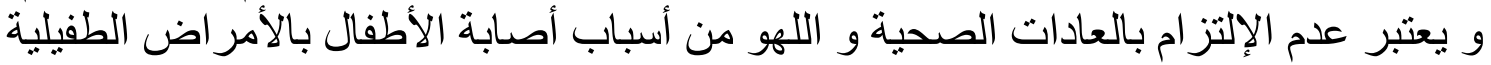

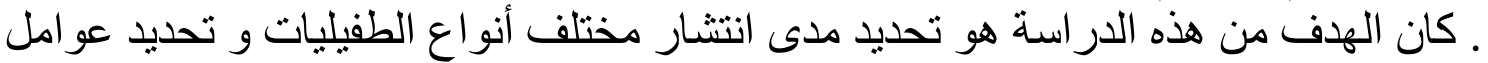

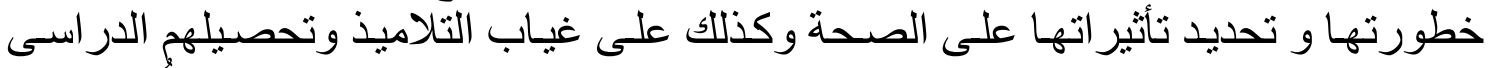

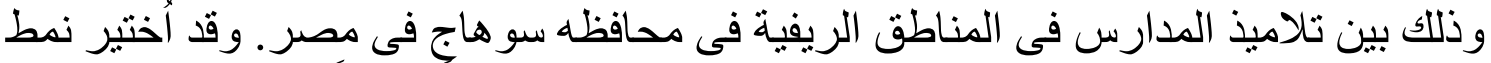

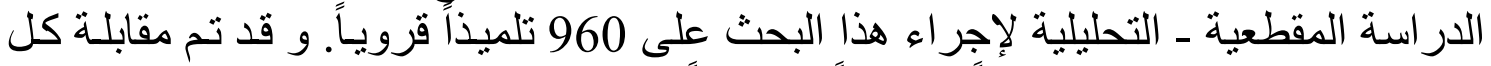

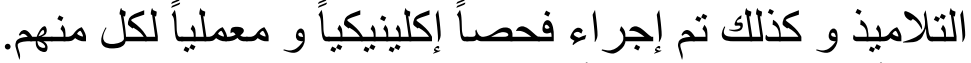

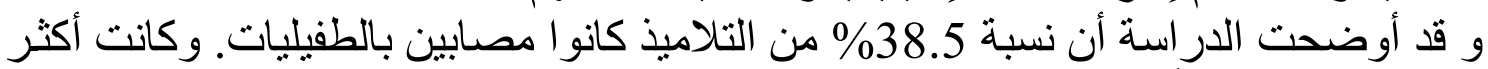

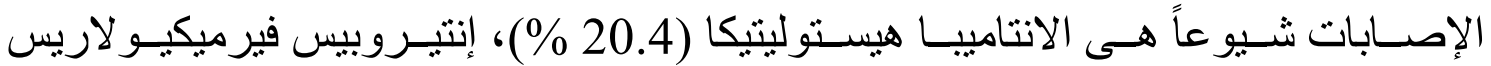

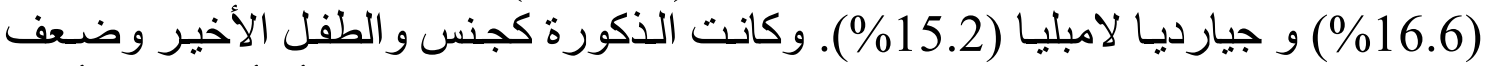

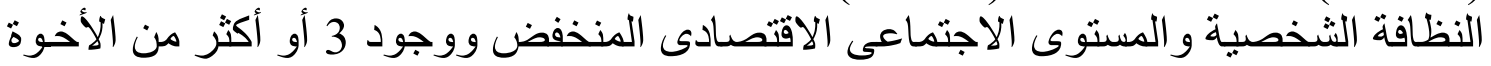

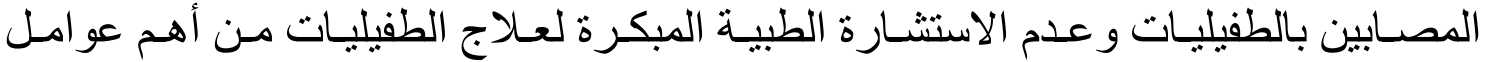

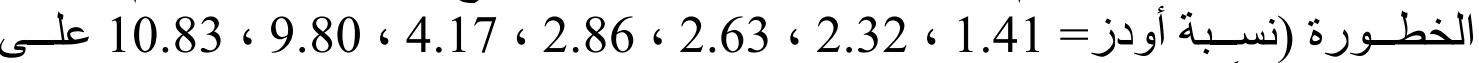

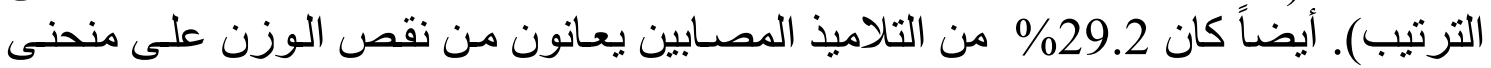

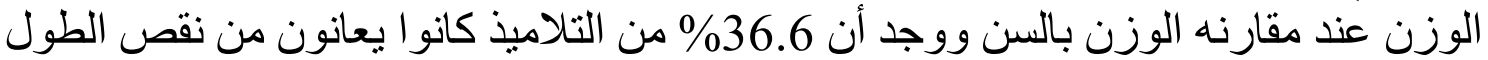

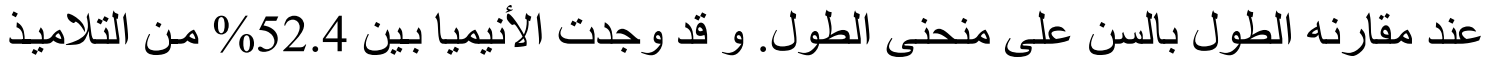

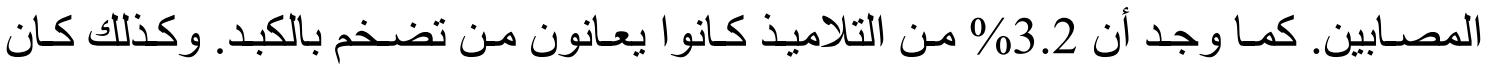

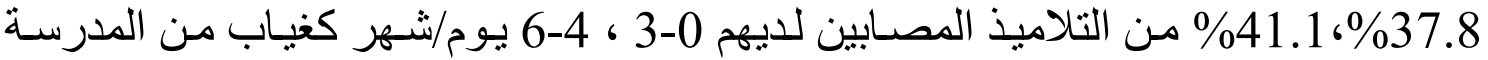

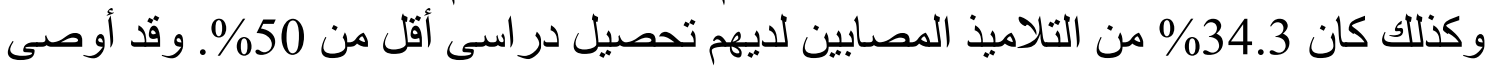
البحث بتحسين النظافة الثخصية و البيئية و عمل المسوحات لاتين والعلاج و التثقيف الصحى بشكل منتظم للطفيليات بين التلاميذ فى مصر. 